\title{
Effect of Neonatal Exposure to Genistein on Bone Metabolism in Mice at Adulthood
}

\author{
ANA V. PIEKARZ AND WENDY E. WARD \\ Department of Nutritional Sciences, Faculty of Medicine, University of Toronto, Toronto, Ontario, Canada, M5S 3E2
}

\begin{abstract}
Infants fed soy-based infant formulas are exposed to high levels of genistein, an isoflavone, with potential estrogen-like activity. This study determined whether neonatal exposure of mice to genistein resulted in higher bone mineral density (BMD) and greater resistance to fracture at adulthood. Male and female CD-1 mice $(n=$ 4-14/group) were randomized to control (CON) (corn oil, s.c.), diethylstilbestrol (DES) (2 $\mu \mathrm{g} / \mathrm{pup} / \mathrm{d}$, s.c.), or genistein (GEN) (4 $\mu \mathrm{g} / \mathrm{pup} / \mathrm{d}$, s.c.) from d 1 through 5 of life. At $21 \mathrm{~d}$ of age, pups were weaned and studied until 4 mo of age when tissues were collected. Among females, femur $(p=0.016)$ and lumbar vertebrae (LV1LV4) $(p<0.001)$ BMD were higher among DES and GEN groups compared with CON group. Importantly, the higher LV1-LV4 BMD was associated with stronger vertebrae that were more resistant to fracture as the peak load of LV3 $(p=0.012)$ was higher in the GEN and DES groups compared with CON group. In males, DES and GEN had divergent effects on femur and lumbar vertebrae BMD and peak load. In conclusion, early exposure to GEN has positive effects on femur and lumbar spine of females, likely due to estrogenic effects, while only the lumbar spine of males benefits from early exposure to GEN. (Pediatr Res 61: 48-53, 2007)
\end{abstract}

$\mathrm{T}$ There is evidence that short-term exposure to estrogen during the first few days of life has positive effects on bone at adulthood. Exposure of female mice to DES during the first $5 \mathrm{~d}$ of life has been shown to decrease the number and activity of osteoclasts that could lead to higher BMD $(1,2)$. Based on these findings, and due to the fact that some infants receive soy infant formula that contains isoflavones with potential estrogen-like activity, the overall objective of this study was to determine whether neonatal exposure of female and male mice to genistein, an isoflavone in soy, resulted in a higher BMD and greater resistance to fractures at adulthood.

Genistein is abundant in soy infant formula. Due to the potential estrogen-like activity of genistein, there is interest in the potential health benefits and/or adverse effects of feeding soy-based infant formulas. Early postnatal life is known to be a developmental stage that is particularly sensitive to hormones. Thus, it is important to consider that the level of isoflavone exposure to infants fed such formulas is extremely high. During the first year of life, infants fed soy-based formula can be exposed to 6-9 $\mathrm{mg}$ of isoflavones $/ \mathrm{kg}$ of body weight/d, more than $65 \%$ of which is genistein, whereas adults

Received June 28, 2006; accepted August 18, 2006.

Correspondence: Wendy E. Ward, Ph.D., Department of Nutritional Sciences, Faculty of Medicine, University of Toronto, Toronto, Ontario, Canada, M5S 3E2; e-mail: wendy.ward@utoronto.ca

DOI: $10.1203 / 01 . p d r .0000250200 .94611 .03$ who consume a diet with modest amounts of soy isoflavones are exposed to approximately $1 \mathrm{mg}$ of isoflavone $/ \mathrm{kg}$ of body weight/d (3). Although studies have shown that feeding soybased infant formula to full-term infants is associated with normal growth and development at $1 \mathrm{y}$ of age $(4,5)$, long-term effects of exposure to high levels of isoflavones such as genistein present in soy-based infant formulas have not been extensively studied. With respect to bone development and metabolism, no studies have reported effects of isoflavone exposure during early life, either in humans or animals, on BMD or biomechanical bone strength properties at adulthood. It is hypothesized that early neonatal exposure to genistein may provide a preventive strategy that optimizes peak bone mass and bone strength, thereby potentially decreasing the risk of developing osteoporosis and fragility fracture later in life.

Some epidemiologic evidence suggests that women with high intake of soy foods have greater protection against osteoporosis (6-8). To date, studies investigating the role of soy or its isoflavone on bone metabolism have focused on their role in preventing bone loss after the cessation of endogenous estrogen production by either studying postmenopausal women or using the ovariectomized rodent model. Most feeding trials in postmenopausal women (9-12) and ovariectomized rodents (13-20) have demonstrated that genistein, either as purified isoflavone or in soy protein isolate, has positive effects on bone outcomes such as BMD. The mechanism of genistein on bone metabolism is not completely understood. The bone-protective effects of genistein may be due to structural similarities between genistein and the human estrogen $17 \beta$-estradiol as genistein may bind to estrogen receptors (ER) in target tissues such as bone (21). Two ER have been identified, ER- $\alpha$ and ER- $\beta$, and both have a pivotal role in bone tissue (22-25). Because genistein can bind to both estrogen receptors, genistein may have significant biologic activity in bone tissue.

The specific objective of this study was to determine whether exposure of female and male mice to genistein during the first $5 \mathrm{~d}$ of life results in a higher BMD and greater biomechanical bone strength properties than mice not exposed to genistein. Two specific skeletal sites, femurs and lumbar spine, were studied to assess skeletal sites that differ in the quantity of cortical and trabecular bone. Both genders were

Abbreviations: BMC, bone mineral content; BMD, bone mineral density; CON, control; DES, diethylstilbestrol; GEN, genistein; ML, mediolateral; PND, postnatal day 
studied inasmuch as females as well as male infants are fed soy-based infant formulas, and osteoporosis affects men as well as women.

\section{METHOD}

Animals and diets. Ten timed-pregnant outbred CD-1 mice were obtained from Charles River Canada (St. Constant, QC). Upon arrival, pregnant females were housed one per cage, kept in standard environment conditions (12-h light:12-h dark cycle, room temperature of $23^{\circ} \mathrm{C}$ ) and fed control diet (AIN93G, Dyets Inc., Bethehem, PA) (26) that is devoid of isoflavones including genistein. Fresh diet was provided every $2-3$ d. Distilled water was consumed ad libitum.

At birth, pups within a litter were randomized to one of three groups. The groups were control (CON, vehicle), diethylstilbestrol (DES), or genistein (GEN). Because it was not possible to determine gender at birth, the sample size per group was not equal [males: $n=7$ (CON), $n=14$ (DES), $n=12$ (GEN); females: $n=11$ (CON), $n=4$ (DES), $n=10$ (GEN)). Control pups received corn oil, which was used as the vehicle for GEN and DES. The DES group received $2 \mu \mathrm{g}$ of DES/pup/d dissolved in corn oil (approximately $2 \mathrm{mg}$ $\mathrm{DES} / \mathrm{kg}$ of body weight $/ \mathrm{d}$ ). This dose of DES was previously shown to favorably modify bone metabolism and served as the positive control (2). The GEN group received $4 \mu \mathrm{g}$ of GEN/pup/d dissolved in corn oil (approximately $4 \mathrm{mg}$ GEN/kg of body weight/d). This dose of genistein is equivalent to the average exposure of infants to isoflavones in soy-based infant formula (3). By design, the doses of GEN and DES used were not equivalent with respect to estrogenicity as it was important to use a dose of GEN that resembles the level of exposure to human infants fed soy-based infant formula. A dose of $100 \mathrm{mg}$ genistein/pup/d would have been required to match the estrogenicity of the DES dose based on the fact that uterotropic assays have demonstrated that DES is 50,000-fold more estrogenic than genistein (27). Pups were injected subcutaneously with a total volume of $0.1 \mathrm{~mL} / \mathrm{pup} / \mathrm{d}$ of corn oil alone or corn oil containing genistein or DES on PND 1 through 5.

At $21 \mathrm{~d}$ of age, pups were weaned, separated by gender and fed fresh diet (AIN93G) every 2-3 d. Distilled water was consumed ad libitum. Body weight was measured once weekly. At 4 mo of age, mice were anesthetized with carbon dioxide for blood collection and subsequently killed by cervical dislocation. Femurs and LV1-LV4 were excised. Testes (males), uterus, and ovaries (females) were removed and weighed.

All experimental procedures respected the policies set out by the Canadian Council on Animal Care (28) and were approved by the University of Toronto Animal Ethics Committee, University of Toronto.

Biochemical markers of bone metabolism. Blood was centrifuged at $10,000 \mathrm{rpm}$ for $15 \mathrm{~min}$ and serum was stored at $-70^{\circ} \mathrm{C}$. Serum osteocalcin and serum collagen crosslinks were measured using commercially available enzyme linked immunoassays specific for mice (mouse osteocalcin, Biotechnologies Inc., Stoughton, MA; RatLaps, Nordic Bioscience Diagnostics, Herlev, Denmark).

$B M C$ and BMD of femurs and lumbar vertebrae (LV1-LV4). BMC and BMD of the left femurs and LV1-LV4 were determined by PIXImus dual energy x-ray absorptiometry (DEXA) (LUNAR Corporation, GE Medical Systems, Mississauga, ON, Canada) using a specialized software program (Lunar Software Version 1.46) as previously described (29). Individual femurs and intact lumbar vertebrae (LV1-LV4) were placed on a plastic tray and scanned in air.
Biomechanical strength properties of femurs and lumbar vertebra 3 (LV3). The biomechanical strength properties of the femur and LV3 were measured by three-point bending and compression testing, respectively, using a materials testing system (Model 4442, Instron Corp., Canton, MA) and specialized software (Series IX Automated Materials Tester, Version 8.15.00).

Three-point bending. Three-point bending was used to determine the structural properties (yield load, resilience, stiffness, peak load, toughness) of right femurs $(29,30)$. Femurs previously cleaned of soft tissue were removed from the freezer and soaked in physiologic saline solution for $3 \mathrm{~h}$. Length and widths of femurs were measured using an electronic precision caliper (Cedarlane Laboratories Ltd., Hornby, ON, Canada). The femur midpoint was determined based on the length of the femur, and mediolateral (width) and anteroposterior (depth) dimensions were measured at the midpoint. The posterior surface of the femur was placed on two 1-mm-wide base supports, positioned $6 \mathrm{~mm}$ apart, such that the load was applied at the femur midpoint. The crosshead lowered at a constant speed of $2 \mathrm{~mm} / \mathrm{min}$ until the femur fractured.

Compression testing. LV3 were soaked in saline and positioned on the center of a stainless-steel plate. The height, width, and depth of each LV3 were measured using an electronic precision caliper. A compressive force was applied by lowering a steel plate at a constant rate of $2 \mathrm{~mm} / \mathrm{min}$ (29). Peak load was determined to be the first peak on the load-displacement curve.

Statistical analysis. Statistical analyses were performed using SigmaStat (Version 2.0, Jandel Scientific, San Rafael, CA). Results are expressed as mean \pm SEM. Two-way ANOVA was performed for most outcomes with gender and treatment as the main effects, and interaction effects (gender $X$ treatment) were assessed. One-way ANOVA was used to analyze weights of testes, uterus, and ovaries. Student-Newman Keul's test was used for comparison of multiple means when statistical differences were observed. Differences were considered significant at $p<0.05$.

\section{RESULTS}

Initial and final body weight and total weight gain. There were no differences in initial body weight due to gender or treatment among groups (Table 1). Gender $(p<0.001)$ but not treatment had a significant effect on final body weight and total weight gain (Table 1). Male mice had higher body weights $(p<0.001)$ and total weight gain $(p<0.001)$ compared with females (Table 1).

Testes, ovaries, and uterus weights. The weights of testes (males), uterus and ovaries (females), expressed either as absolute weight (not shown) or corrected to account for body weight (Table 2), were not different among the three groups.

Femur outcomes: weight, dimensions, BMC, BMD, and biomechanical strength properties. Femur weight was significantly different due to gender $(p=0.023)$ and treatment $(p<$ 0.030), with genistein and DES groups having greater femur weight than control group (Table 3). Female control mice had

Table 1. Initial and final body weights, and total weight gain*

\begin{tabular}{|c|c|c|c|c|c|c|}
\hline & Treatment & Males & Females & Gender & Treatment & Gender $\times$ treatment \\
\hline \multirow[t]{3}{*}{ Initial body weight $(\mathrm{g}) \dagger$} & $\mathrm{CON}$ & $12.23 \pm 0.62$ & $10.93 \pm 0.49$ & & & \\
\hline & DES & $12.15 \pm 0.43$ & $11.22 \pm 0.81$ & NS & NS & NS \\
\hline & GEN & $11.62 \pm 0.47$ & $12.32 \pm 0.51$ & & & \\
\hline \multirow{2}{*}{ Final body weight $(\mathrm{g}) \ddagger$} & DES & $44.63 \pm 1.68$ & $31.27 \pm 2.90$ & $<0.001$ & NS & NS \\
\hline & GEN & $49.14 \pm 1.68$ & $34.04 \pm 1.84$ & & & \\
\hline Total weight gain $(\mathrm{g}) \S$ & $\mathrm{CON}$ & $32.73 \pm 1.95$ & $19.22 \pm 1.56$ & & & \\
\hline
\end{tabular}

* Values are expressed as mean \pm SEM. Males: $n=7(\mathrm{CON}) ; n=14(\mathrm{DES}) ; n=12(\mathrm{GEN})$. Females: $n=11(\mathrm{CON}) ; n=4(\mathrm{DES}) ; n=10(\mathrm{GEN})$.

$\dagger$ Body weight at weaning, PND 21.

$\ddagger$ Body weight at necropsy, PND 120 .

$\S$ Calculated by subtracting body weight at weaning (PND 21) from body weight at necropsy (PND 120). 
Table 2. Testes, ovaries and uterus weights*

\begin{tabular}{ccc}
\hline Treatment & $\begin{array}{c}\text { Testes } \\
\text { (mg/g body weight) }\end{array}$ & $\begin{array}{c}\text { Ovaries }+ \text { uterus } \\
\text { (mg/g body weight) }\end{array}$ \\
\hline CON & $5.13 \pm 0.24$ & $4.81 \pm 0.49$ \\
DES & $4.91 \pm 0.15$ & $3.71 \pm 0.69$ \\
GEN & $4.26 \pm 0.07$ & $5.37 \pm 0.88$ \\
$p$ value & 0.159 & 0.439 \\
\hline
\end{tabular}

* Values are expressed as mean \pm SEM. Males: $n=7(\mathrm{CON}) ; n=14$ (DES); $n=12$ (GEN). Females: $n=11$ (CON); $n=4$ (DES); $n=10(\mathrm{GEN})$.

lower ( $p=0.001$ ) femur weights than all other groups (Table 3). Femur length and depth [anteroposterior (AP) width] did not differ due to gender or treatment (Table 3). Width [mediolateral (ML) width] of male mice was higher than female mice $(p<0.001)$ (Table 3). Genistein treatment resulted in greater $(p=0.019)$ width (ML width) than control and DES treatment (Table 3).

Femur BMC was significantly higher $(p=0.019)$ among males compared with females while treatment had no significant effect (Table 4). There was an interaction between gender and treatment for femur BMC. Females treated with
DES had greater $(p=0.015)$ BMC than CON females and males treated with DES; and males treated with GEN had a higher $(p=0.015)$ BMC than males treated with DES or control females (Table 4). With respect to femur BMD, DES and genistein treatment resulted in greater $(p=0.016)$ femur BMD than controls (Table 4). There was a significant interaction of gender $\times$ treatment for femur BMD $(p=0.001)$ (Table 4). Females who received DES and GEN, and males treated with GEN had a higher $(p<0.001)$ BMD than female controls and males treated with DES (Table 4). There were no differences in femur yield load, resilience, or ultimate stiffness among groups (Table 4). There was a significant interaction of gender $\times$ treatment for femur peak load (Table 4). Females treated with DES and males treated with GEN had a higher peak load than female controls and males treated with DES (Table 4).

Dimensions of lumbar vertebrae 3 (LV3), BMC and BMD of LV1-LV4, and peak load of LV3. Gender and treatment had no significant effect on the dimensions of LV3 (Table 5). GEN and DES treatment resulted in higher $(p<0.001)$ BMC of LV1-LV4 but gender did not have a significant effect (Table 6). Males had higher ( $p=0.028$ ) BMD of LV1-LV4

Table 3. Femur weight and dimensions*

\begin{tabular}{|c|c|c|c|c|c|c|}
\hline & Treatment & Males & Females & Gender & Treatment & Gender $\times$ treatment \\
\hline \multirow[t]{3}{*}{ Weight (mg) } & $\mathrm{CON}$ & $120.01 \pm 0.01^{\mathrm{a}}$ & $100.01 \pm 0.01^{b}$ & & & \\
\hline & DES & $120.00 \pm 0.01^{\mathrm{a}}$ & $120.00 \pm 0.02^{\mathrm{a}}$ & 0.023 & 0.030 & $<0.01$ \\
\hline & GEN & $130.01 \pm 0.01^{\mathrm{a}}$ & $120.01 \pm 0.01^{\mathrm{a}}$ & & & \\
\hline \multirow{2}{*}{ Length (mm) } & DES & $15.98 \pm 0.12$ & $15.98 \pm 0.20$ & NS & NS & NS \\
\hline & GEN & $16.25 \pm 0.12$ & $15.92 \pm 0.13$ & & & \\
\hline $\operatorname{Depth} \dagger(\mathrm{mm})$ & $\mathrm{CON}$ & $1.46 \pm 0.04$ & $1.39 \pm 0.03$ & & & \\
\hline \multirow[t]{3}{*}{ Width $\ddagger(\mathrm{mm})$} & $\mathrm{CON}$ & $1.87 \pm 0.07$ & $1.59 \pm 0.06$ & & & \\
\hline & DES & $1.81 \pm 0.06$ & $1.64 \pm 0.09$ & $<0.001$ & 0.019 & NS \\
\hline & GEN & $2.08 \pm 0.06$ & $1.69 \pm 0.06$ & & & \\
\hline
\end{tabular}

* Values are expressed as mean \pm SEM. Males: $n=7(\mathrm{CON}) ; n=14(\mathrm{DES}) ; n=12(\mathrm{GEN})$. Females: $n=11(\mathrm{CON}) ; n=4(\mathrm{DES}) ; n=10(\mathrm{GEN})$. Values with different letters for an outcome are significantly different, $p<0.05$.

$\dagger$ Depth refers to the anteroposterior width at the midpoint of the femur.

$\ddagger$ Width refers to the mediolateral width at the midpoint of the femur.

Table 4. Femur BMC, BMD, and biomechanical strength properties*

\begin{tabular}{|c|c|c|c|c|c|c|}
\hline & Treatment & Males & Females & Gender & Treatment & Gender $\times$ treatment \\
\hline \multirow[t]{3}{*}{$\mathrm{BMC}(\mathrm{mg})$} & $\mathrm{CON}$ & $39.50 \pm 1.66^{\mathrm{ab}}$ & $33.62 \pm 1.32^{\mathrm{b}}$ & & & \\
\hline & DES & $37.11 \pm 1.22^{\mathrm{b}}$ & $39.85 \pm 2.19^{\mathrm{a}}$ & 0.019 & 0.056 & 0.015 \\
\hline & GEN & $43.08 \pm 1.27^{\mathrm{a}}$ & $37.05 \pm 1.39^{\mathrm{ab}}$ & & & \\
\hline \multirow{2}{*}{$\mathrm{BMD}\left(\mathrm{mg} / \mathrm{cm}^{2}\right)$} & DES & $74.07 \pm 1.32^{\mathrm{b}}$ & $82.67 \pm 2.38^{\mathrm{a}}$ & NS & 0.016 & $<0.001$ \\
\hline & GEN & $79.12 \pm 1.38^{\mathrm{a}}$ & $75.82 \pm 1.51^{\mathrm{a}}$ & & & \\
\hline Yield load (N) & $\mathrm{CON}$ & $14.65 \pm 1.39$ & $15.49 \pm 1.07$ & & & \\
\hline \multirow[t]{3}{*}{ Peak load (N) } & $\mathrm{CON}$ & $32.71 \pm 1.76^{\mathrm{ab}}$ & $29.72 \pm 1.37^{\mathrm{b}}$ & & & \\
\hline & DES & $30.92 \pm 1.30^{\mathrm{b}}$ & $36.26 \pm 2.16^{\mathrm{a}}$ & NS & NS & 0.015 \\
\hline & GEN & $35.88 \pm 1.30^{\mathrm{a}}$ & $32.11 \pm 1.37^{\mathrm{ab}}$ & & & \\
\hline \multirow[t]{3}{*}{ Ultimate stiffness (N/mm) } & $\mathrm{CON}$ & $238.03 \pm 19.39$ & $228.13 \pm 15.02$ & & & \\
\hline & DES & $238.32 \pm 14.32$ & $307.55 \pm 23.75$ & NS & NS & NS \\
\hline & GEN & $256.50 \pm 14.32$ & $253.55 \pm 15.02$ & & & \\
\hline
\end{tabular}

* Values are expressed as mean \pm SEM. Males: $n=7(\mathrm{CON}) ; n=14(\mathrm{DES}) ; n=12(\mathrm{GEN})$. Females: $n=11(\mathrm{CON}) ; n=4(\mathrm{DES}) ; n=10(\mathrm{GEN})$. Values with different letters for an outcome are significantly different, $p<0.05$. 
Table 5. Dimensions of Lumbar Vertebra 3 (LV3)*

\begin{tabular}{|c|c|c|c|c|c|c|}
\hline & Treatment & Males & Females & Gender & Treatment & Gender $\times$ treatment \\
\hline \multirow[t]{3}{*}{ Height (mm) } & $\mathrm{CON}$ & $3.94 \pm 0.13$ & $3.88 \pm 0.10$ & & & \\
\hline & DES & $3.80 \pm 0.09$ & $3.61 \pm 0.17$ & NS & NS & NS \\
\hline & GEN & $3.63 \pm 0.10$ & $3.72 \pm 0.11$ & & & \\
\hline \multirow{2}{*}{ Weight (mg) } & DES & $42.26 \pm 0.31$ & $38.55 \pm 3.06$ & NS & NS & NS \\
\hline & GEN & $40.52 \pm 0.73$ & $37.87 \pm 2.04$ & & & \\
\hline Depth $\dagger(\mathrm{mm})$ & $\mathrm{CON}$ & $3.43 \pm 0.08$ & $3.32 \pm 0.07$ & & & \\
\hline \multirow[t]{3}{*}{ Width $\neq(\mathrm{mm})$} & $\mathrm{CON}$ & $3.49 \pm 0.09$ & $3.43 \pm 0.07$ & & & \\
\hline & DES & $3.54 \pm 0.07$ & $3.39 \pm 0.12$ & NS & NS & NS \\
\hline & GEN & $3.51 \pm 0.07$ & $3.49 \pm 0.08$ & & & \\
\hline
\end{tabular}

* Values are expressed as mean \pm SEM. Males: $n=7(\mathrm{CON}) ; n=14(\mathrm{DES}) ; n=12$ (GEN). Females: $n=11(\mathrm{CON}) ; n=4(\mathrm{DES}) ; n=10(\mathrm{GEN})$.

$\dagger$ Depth refers to the anteroposterior width of LV3.

$\ddagger$ Width refers to the mediolateral width of LV3.

Table 6. BMC and BMD of lumbar vertebrae (LV1-LV4) and peak load of LV3*

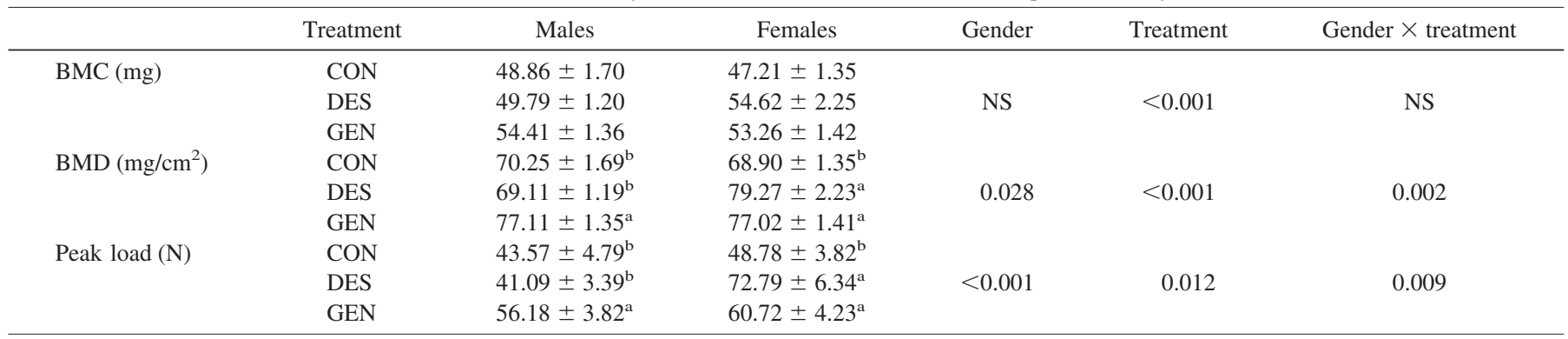

* Values are expressed as mean \pm SEM. Males: $n=7(\mathrm{CON}) ; n=14$ (DES); $n=12$ (GEN). Females: $n=11(\mathrm{CON}) ; n=4(\mathrm{DES}) ; n=10(\mathrm{GEN})$. Values with different letters for an outcome are significantly different, $p<0.05$.

Table 7. Biochemical markers of bone metabolism: serum osteocalcin and serum collagen crosslinks*

\begin{tabular}{lcccccc}
\hline & Treatment & Males & Females & Gender & Treatment & Gender $\times$ treatment \\
\hline Osteocalcin $(\mathrm{ng} / \mathrm{mL})$ & CON & $143.28 \pm 14.36^{\mathrm{b}}$ & $193.66 \pm 12.67^{\mathrm{a}}$ & & & NS \\
& DES & $82.73 \pm 10.54^{\mathrm{c}}$ & $203.85 \pm 19.00^{\mathrm{a}}$ & $<0.001$ & 0.002 \\
& GEN & $67.81 \pm 11.46^{\mathrm{c}}$ & $213.34 \pm 12.67^{\mathrm{a}}$ & & & \\
Collagen crosslinks $(\mathrm{ng} / \mathrm{mL})$ & CON & $23.49 \pm 2.32^{\mathrm{a}}$ & $20.90 \pm 2.04^{\mathrm{ab}}$ & & \multirow{2}{*}{0.019} \\
& DES & $18.72 \pm 1.70^{\mathrm{abc}}$ & $26.39 \pm 3.06^{\mathrm{a}}$ & 0.013 & \\
& GEN & $14.38 \pm 1.85^{\mathrm{c}}$ & $22.25 \pm 2.04^{\mathrm{ab}}$ & & & \\
\hline
\end{tabular}

* Values are expressed as mean \pm SEM. Males: $n=7(\mathrm{CON}) ; n=14(\mathrm{DES}) ; n=12$ (GEN). Females: $n=11(\mathrm{CON}) ; n=4(\mathrm{DES}) ; n=10(\mathrm{GEN})$. Values with different letters for an outcome are significantly different, $p<0.05$.

than females. Furthermore, treatment with DES or GEN resulted in higher $(p<0.001)$ BMD than CON (Table 6). There was a significant interaction $(p=0.002)$ of gender $\times$ treatment for BMD of LV1-LV4 (Table 6). Males and females treated with GEN had a higher $(p=0.002)$ BMD than all other groups except females treated with DES (Table 6). Peak load of LV3 was higher $(p<0.001)$ among males compared with females; and higher $(p=0.012)$ among DES and GEN groups compared with CON groups (Table 6). There was a significant interaction between gender and treatment for peak load $(p=0.009)$ (Table 6). Male and females treated with GEN and females treated with DES had a higher $(p=0.09)$ peak load than all other groups (Table 6).

Biochemical markers: serum osteocalcin and serum collagen crosslinks. Serum osteocalcin $(p<0.001)$ and collagen crosslinks $(p<0.013)$ were significantly higher among females compared with males (Table 7). For both serum osteo- calcin and collagen crosslinks there was a significant interaction of gender $\times$ treatment $(p=0.002$ osteocalcin, $p=0.019$ collagen crosslinks) (Table 7).

\section{DISCUSSION}

This study reports the effects of short-term exposure to genistein, a soy isoflavone, during the first $5 \mathrm{~d}$ of postnatal life on bone outcomes at adulthood in male and female mice. These outcomes included BMD as well as functional outcomes of bone, i.e. biomechanical strength properties of femurs and lumbar spine. Measurement of the biomechanical strength properties is of particular relevance as these outcomes are surrogate measures of fracture risk. A novel finding of this study is that exposure to isoflavones during the earliest stages of postnatal life results in altered bone metabolism at adulthood. To date, most studies investigating the effects of soy 
isoflavones on bone metabolism have been in states of estrogen withdrawal.

Our findings that femur BMD and LV1-LV4 BMD were higher among DES-treated female mice compared with controls was expected based on a previous study that reported that transient exposure to DES during early development altered osteoclastogenesis due to a permanent effect on the bone microenvironment in female mice (2). The present study used the same dose of DES as in previous reports $(1,2)$. The fact that the GEN-treated female mice, like the DES-treated mice, had a higher femur BMD than controls suggests that genistein was acting by an estrogen-like mechanism. In the GEN group, the higher femur BMD was not associated with a greater peak load, the ultimate measure of fracture resistance. However, greater fracture resistance (i.e. peak load of LV3) was observed in the lumbar spine. Both the BMD of LV1-LV4 and the peak load of LV3 were significantly higher in the GEN treated females compared with control group, indicating that trabecular bone was more responsive to genistein intervention than cortical bone. In female mice, both the femur and lumbar vertebrae data suggest that genistein is acting like estrogen. This is an interesting finding since the estrogenicity of the dose of genistein was substantially lower than the dose of DES and yet similar biologic effects are observed. In contrast to female mice, DES and GEN groups in males had divergent effects on femur BMD and peak load, as well as lumbar spine BMD and peak load of LV3. Males treated with GEN had higher lumbar spine BMD and peak load of LV4 compared with both the DES and CON group while femur outcomes did not differ between the GEN and CON group, suggesting a site-specific effect of genistein on skeletal health in males. The mechanism of action of genistein in males remains to be determined.

The biochemical bone marker data also suggest that females and males respond differently to neonatal exposure to DES or GEN. The fact that neither serum levels of osteocalcin nor collagen crosslinks differed significantly among female groups suggests that differences in bone turnover were not evident at 4 mo of age but occurred at an earlier stage of life. In contrast, among males, mice treated with GEN had lower levels of serum collagen and serum collagen crosslinks compared with controls, suggesting a lower rate of bone turnover was present when mice were killed at 4 mo of age. The timing of when differences in rates of bone turnover occurred requires further study. Whether or not the lower rate of bone turnover among males persists into older ages, and the potential implications to bone health, requires investigation. Similarly, whether higher femur and lumbar vertebrae BMD is protective among females treated with GEN after cessation of endogenous estrogen production remains to be determined.

Human and animal studies on metabolic imprinting have demonstrated that exposure to specific nutrients during early life can affect risk of chronic diseases during adulthood (31$35)$. Genistein may be acting directly on ER in bone cells, setting the metabolic pathway that will be stored throughout life, despite cellular replication and replacement. Findings from cell culture studies suggest that genistein may have stimulated osteoblastic activity and decreased osteoclastic ac- tivity in the present study. Isoflavones such as genistein can stimulate osteoblastic activity, demonstrated by increased production of alkaline phosphatase and bone nodule formation, markers of early and late osteoblastic differentiation, respectively $(36,37)$. These effects may be mediated via increased production of bone morphogenetic protein-2, an important regulator of osteogenesis (37). Another study, using human osteosarcoma osteoblasts, also reported that genistein stimulated synthesis of collagen and alkaline phosphatase, and ultimately resulted in mineralized bone modules (38). In orchidectomized rats, feeding soy isoflavones resulted in elevated mRNA levels of type I collagen, alkaline phosphatase, and osteocalcin, demonstrating that effects of genistein are not exclusive to females (39). Genistein has also been shown to act as a tyrosine kinase inhibitor, resulting in a decreased number of osteoclasts $(40,41)$, and may modulate osteoclastogenesis by regulating mRNA expression of receptor activator of NF-B ligand (RANKL) and osteoprotegerin (42).

Safety is an important issue to consider when extrapolating these study findings to infants fed soy-based formula. Early exposure to estrogenic compounds, namely DES, is associated with an increase in genital tract abnormalities in female mice $(43,44)$ and an alteration of reproductive functions in males (45). In humans, adenocarcinoma of the vagina has been reported in young women whose mothers were exposed to DES during pregnancy (46). These changes could be related to the steroid dose or to the duration and age of exposure. It is encouraging that findings from the present study indicate that early exposure to genistein, at the levels to which infants fed soy-based formula are exposed, did not have an effect on sex organ weights. However, because organ weight does not fully address potential teratogenic or carcinogenic effects of environmental estrogenic compounds, histology of organs should be performed in future studies. It would be particularly useful to perform histologic analyses of tissues from older animals as negative effects due to transient exposure may not be manifested until later stages of life. Thorough examination of reproductive indices, such as fertility, is required as long-term effects of soy-based infant formula on reproductive health have not been extensively studied. One retrospective cohort study compared young men and women who received soy formula with those who had received cow's milk formula during infancy (47). No statistically significant differences were observed in adult height, weight, body mass index, pubertal maturation, or fertility as measured by pregnancy, miscarriage, or ectopic pregnancy rates. Women fed soybased formula reported slightly longer duration of menstrual bleeding and greater discomfort with menstruation, with no difference in severity of menstrual flow. There were no differences in cancer, reproductive organ or hormonal disorders, sexual orientation, libido dysfunction or birth defects between infants fed soy or cow's milk formula. Future studies should continue to study the effects of early exposure to isoflavones since neonatal exposure to genistein, at a dose similar to the present study ( $5 \mu \mathrm{g} / \mathrm{pup} / \mathrm{d})$, reported altered estrous cycles and impaired fertility (43). Abnormal ovulation in mice treated with slightly higher levels of genistein ( $10 \mu \mathrm{g} / \mathrm{pup} / \mathrm{d})$ has also been reported (48). 
In conclusion, short-term exposure to genistein during the first $5 \mathrm{~d}$ of postnatal life resulted in improved femur and lumbar spine outcomes among female mice, with a positive effect on only lumbar spine among male mice. Early exposure to genistein may provide a preventive strategy that optimizes peak bone mass and bone strength, thereby potentially decreasing the risk of developing osteoporosis and fragility fracture later in life. Because the dose of genistein administered to the mice was similar to the level of exposure to infants fed soy based infant formula on a body weight basis, the findings from this study provide the basis for human studies in which peak bone mass and other measures of bone health may be assessed in adults who consumed soy-based infant formula during early life. In this study, bone outcomes were assessed at an age when mice have attained their peak bone mass. Whether the higher vertebral BMD and peak load at adulthood protect against bone loss and fracture during aging are unknown.

Acknowledgments. The authors thank Susie Kim for technical assistance and NSERC for her summer studentship.

\section{REFERENCES}

1. Migliaccio S, Newbold RR, Bullock BC, Jefferson WJ, Sutton FG Jr, McLachlan JA, Korach KS 1996 Alterations of maternal estrogen levels during gestation affect the skeleton of female offspring. Endocrinology 137:2118-2125

2. Migliaccio S, Newbold RR, Teti A, Jefferson WJ, Toverud SU, Taranta A, Bullock BC, Suggs CA, Spera G, Korach KS 2000 Transient estrogen exposure of female mice during early development permanently affects osteoclastogenesis in adulthood. Bone 27:47-52

3. Setchell KD, Zimmer-Nechemias L, Cai J, Heubi JE 1997 Exposure of infants to phyto-oestrogens from soy-based infant formula. Lancet 350:23-27

4. American Academy of Pediatrics, Committee on Nutrition 1998 Soy protein-based formulas: recommendations for use in infant feeding. Pediatrics 101:148-153.

5. Steichen JJ, Tsang RC 1987 Bone mineralization and growth in term infants fed soy-based or cow milk-based formula. J Pediatr 110:687-692

6. Mei J, Yeung SS, Kung AW 2001 High dietary phytoestrogen intake is associated with higher bone mineral density in postmenopausal but not premenopausal women. J Clin Endocrinol Metab 86:5217-5221

7. Horiuchi T, Onouchi T, Takahashi M, Ito H, Orimo H 2000 Effect of soy protein on bone metabolism in postmenopausal Japanese women. Osteoporos Int 11:721-724

8. Ho SC, Chan SG, Yi Q, Wong E, Leung PC 2001 Soy intake and the maintenance of peak bone mass in Hong Kong Chinese women. J Bone Miner Res 16:1363-1369

9. Morabito N, Crisafulli A, Vergara C, Gaudio A, Lasco A, Frisina N, D'Anna R, Corrado F, Pizzoleo MA, Cincotta M, Altavilla D, Ientile R, Squadrito F 2002 Effects of genistein and hormone-replacement therapy on bone loss in early postmenopausal women: a randomized double-blind placebo-controlled study. J Bone Miner Res 17:1904-1912

10. Potter SM, Baum JA, Teng H, Stillman RJ, Shay NF, Erdman JW Jr 1998 Soy protein and isoflavones: their effects on blood lipids and bone density in postmenopausal women. Am J Clin Nutr 68:1375S-1379S

11. Alekel DL, Germain AS, Peterson CT, Hanson KB, Stewart JW, Toda T 2000 Isoflavone-rich soy protein isolate attenuates bone loss in the lumbar spine of perimenopausal women. Am J Clin Nutr 72:844-852

12. Atkinson C, Compston JE, Day NE, Dowsett M, Bingham SA 2004 The effects of phytoestrogen isoflavones on bone density in women: a double-blind, randomized, placebo-controlled trial. Am J Clin Nutr 79:326-333

13. Anderson JJ, Ambrose WW, Garner SC 1998 Biphasic effects of genistein on bone tissue in the ovariectomized, lactating rat model. Proc Soc Exp Biol Med 217:345350

14. Fanti P, Monier-Faugere MC, Geng Z, Schmidt J, Morris PE, Cohen D, Malluche HH 1998 The phytoestrogen genistein reduces bone loss in short-term ovariectomized rats. Osteoporos Int 8:274-281

15. Ishimi Y, Miyaura C, Ohmura M, Onoe Y, Sato T, Uchiyama Y, Ito M, Wang X, Suda T, Ikegami S 1999 Selective effects of genistein, a soybean isoflavone, on B-lymphopoiesis and bone loss caused by estrogen deficiency. Endocrinology 140:1893-1900

16. Arjmandi BH, Birnbaum R, Goyal NV, Getlinger MJ, Juma S, Alekel L, Hasler CM, Drum ML, Hollis BW, Kukreja SC 1998 Bone-sparing effect of soy protein in ovarian hormone-deficient rats is related to its isoflavone content. Am J Clin Nutr 68:1364S-1368S

17. Arjmandi BH, Getlinger MJ, Goyal NV, Alekel L, Hasler CM, Juma S, Drum ML, Hollis BW, Kukreja SC 1998 Role of soy protein with normal or reduced isoflavone content in reversing bone loss induced by ovarian hormone deficiency in rats. Am J Clin Nutr 68:1358S-1363S.

18. Picherit C, Coxam V, Bennetau-Pelissero C, Kati-Coulibaly S, Davicco MJ, Lebecque P, Barlet JP 2000 Daidzein is more efficient than genistein in preventing ovariectomy-induced bone loss in rats. J Nutr 130:1675-1681

19. Picherit C, Bennetau-Pelissero C, Chanteranne B, Lebecque P, Davicco MJ, Barlet JP, Coxam V 2001 Soybean isoflavones dose-dependently reduce bone turnover but do not reverse established osteopenia in adult ovariectomized rats. J Nutr 131:723728

20. Picherit C, Chanteranne B, Bennetau-Pelissero C, Davicco MJ, Lebecque P, Barlet JP, Coxam V 2001 Dose-dependent bone-sparing effects of dietary isoflavones in the ovariectomised rat. Br J Nutr 85:307-316

21. Setchell KD, Cassidy A 1999 Dietary isoflavones: biological effects and relevance to human health. J Nutr 129:758S-767S.

22. Chagin AS, Lindberg MK, Andersson N, Moverare S, Gustafsson JA, Savendahl L, Ohlsson C 2004 Estrogen receptor-beta inhibits skeletal growth and has the capacity to mediate growth plate fusion in female mice. J Bone Miner Res 19:72-77

23. Hillisch A, Peters O, Kosemund D, Muller G, Walter A, Schneider B, Reddersen G, Elger W, Fritzemeier KH 2004 Dissecting physiological roles of estrogen receptor alpha and beta with potent selective ligands from structure-based design. Mol Endocrinol 18:1599-1609

24. Lee K, Jessop H, Suswillo R, Zaman G, Lanyon L 2003 Endocrinology: bone adaptation requires oestrogen receptor-alpha. Nature 424:389-

25. Lee KC, Jessop H, Suswillo R, Zaman G, Lanyon LE 2004 The adaptive response of bone to mechanical loading in female transgenic mice is deficient in the absence of oestrogen receptor-alpha and -beta. J Endocrinol 182:193-201

26. Reeves PG 1997 Components of the AIN-93 diets as improvements in the AIN-76A diet. J Nutr 127:838S-841S

27. Jefferson WN, Newbold RR 2000 Potential endocrine-modulating effects of various phytoestrogens in the diet. Nutrition 16:658-662

28. Canadian Council on Animal Care 1993 Guide to the Care and Use of Experimental Animals, Ottawa, ON, pp 1-211.

29. Fonseca D, Ward WE 2004 Daidzein together with high calcium preserve bone mass and biomechanical strength at multiple sites in ovariectomized mice. Bone 35:489497

30. Ealey KN, Fonseca D, Archer MC, Ward WE Bone abnormalities in adolescent leptin-deficient mice. Regul Pept 136:9-13.

31. Barker DJ 2003 The developmental origins of adult disease. Eur J Epidemiol 18:733-736

32. Barker DJ 2004 Developmental origins of adult health and disease. J Epidemiol Community Health 58:114-115

33. Barker DJ 2004 The developmental origins of adult disease. J Am Coll Nutr 23:588S-595S.

34. Lucas A 1998 Programming by early nutrition: an experimental approach. J Nutr 128:401S-406S.

35. Young LE 2001 Imprinting of genes and the Barker hypothesis. Twin Res 4:307-317

36. Chang H, Jin TY, Jin WF, Gu SZ, Zhou YF 2003 Modulation of isoflavones on bone-nodule formation in rat calvaria osteoblasts in vitro. Biomed Environ Sci $16: 83-89$

37. Jia TL, Wang HZ, Xie LP, Wang XY, Zhang RQ 2003 Daidzein enhances osteoblast growth that may be mediated by increased bone morphogenetic protein (BMP) production. Biochem Pharmacol 65:709-715

38. Morris C, Thorpe J, Ambrosio L, Santin M 2006 The soybean isoflavone genistein induces differentiation of MG63 human osteosarcoma osteoblasts J Nutr 136:1166-1170

39. Soung DY, Devareddy L, Khalil DA, Hooshmand S, Patade A, Lucas EA, Arjmand BH 2006 Soy affects trabecular microarchitecture and favorably alters select bonespecific gene expressions in a male rat model of osteoporosis. Calcif Tissue Int 78:385-391

40. Sliwinski L, Folwarczna J, Janiec W, Grynkiewicz G, Kuzyk K 2005 Differential effects of genistein, estradiol and raloxifene on rat osteoclasts in vitro. Pharmacol Rep 57:352-359

41. Gao YH, Yamaguchi M 2000 Suppressive effect of genistein on rat bone osteoclasts: involvement of protein kinase inhibition and protein tyrosine phosphatase activation. Int J Mol Med 5:261-267

42. Chen WF, Wong MS 2006 Genistein modulates the effects of parathyroid hormone in human osteoblastic SaOS-2 cells. Br J Nutr 95:1039-1047

43. Jefferson WN, Padilla-Banks E, Newbold RR 2005 Adverse effects on female development and reproduction in cd-1 mice following neonatal exposure to the phytoestrogen genistein at environmentally relevant doses. Biol Reprod 73:798806

44. McLachlan JA, Newbold RR, Bullock BC 1980 Long-term effects on the female mouse genital tract associated with prenatal exposure to diethylstilbestrol. Cancer Res 40:3988-3999

45. Goyal HO, Robateau A, Braden TD, Williams CS, Srivastava KK, Ali K 2003 Neonatal estrogen exposure of male rats alters reproductive functions at adulthood. Biol Reprod 68:2081-2091

46. Herbst AL 1999 Diethylstilbestrol and adenocarcinoma of the vagina. Am J Obste Gynecol 181:1576-1578

47. Strom BL, Schinnar R, Ziegler EE, Barnhart KT, Sammel MD, Macones GA, Stallings VA, Drulis JM, Nelson SE, Hanson SA 2001 Exposure to soy-based formula in infancy and endocrinological and reproductive outcomes in young adulthood. JAMA 286:807-814

48. Jefferson WN, Couse JF, Padilla-Banks E, Korach KS, Newbold RR 2002 Neonatal exposure to genistein induces estrogen receptor (ER)alpha expression and multioocyte follicles in the maturing mouse ovary: evidence for ERbeta-mediated and nonestrogenic actions. Biol Reprod 67:1285-1296 